\title{
Perception on mathematical difficulties in senior adults
}

\author{
Pilar Moreno-Crespo ${ }^{1 a}$ \\ ${ }^{1}$ Universidad de Huelva, Spain
}

\begin{abstract}
The importance that Life Long Learning currently has, entails reinforcing educational policies in adults and older adults. We have studied the perception about the difficulties of calculation in older adults who are participating in educational activities. In the same way, we analyze which are the factors that influence to a greater extent in a negative perception on the mathematical difficulties. The sample is 448 subjects. The questionnaire is a Likert scale. On the data obtained, we point out that, in general terms, they consider that they are not slow in carrying out calculation operations and that they have no difficulty understanding the mathematical concepts. Likewise, we found correlation $(p<0.001)$ in factors that lead us to affirm that they perceive more difficulties in the calculation, as well as those who have carried out primary studies and whose occupation is focused on the housekeeping.
\end{abstract}

Keywords: mathematical difficulties, perception, senior adults

\section{Introduction}

Nowadays exist an "aging population" in constant growth, with an important interest in forming and involved in educational activities. The positive influence of a socioeducational environment on the elderly is linked to active aging and quality of life. The importance that Life Long Learning (LLL) currently has, entails reinforcing socioeducational policies in adults and older adults $[1,2,4,5,6,7,8,10]$. In the words of SabánVera [12, p. 204], the LLL: "From its different perspectives covers a great variety of objectives, pursues a high degree of well-being and is linked to multiple causes." Similarly, we can affirm that [6, p. 115]: "Permanent education is provided as an essential resource for the advancement of society."

The positive influence of these university programs on active aging and quality of life is evident in the increasing presence of these in the training landscape in developed and developing countries as well as in the enormous scientific production in this regard. In the last decade, the International Congresses have debated on this tripartite theme: education in the elderly, active aging and quality of life. A number of international conferences have

${ }^{\text {a }}$ Corresponding author: pilar.moreno@dedu.uhu.es 
been held that have influenced the recognition and strengthening of the concept of lifelong education $[3,9,11,12]$. The current importance of LLL involves reforms in educational policies for adults and the elderly.

In relation to this evolution, we point to a series of determinants that make LLL necessary [9]: a) The explosion of knowledge and recent scientific advances present a challenge to the education; B) The ever deeper knowledge of a material; C) Scientific and technological changes have not only been quantitative but also qualitative; (D) Deep transformations are occurring under the horizon of globalization; E) The world of work presents new demands every time; F) The democratization of education is making it increasingly seen as an activity available to all.

The LLL includes adult education, which is where we focus on this article. According to Sarrate and Pérez[13, p. 44], adult education is "[...] all formative action that tends to provide knowledge and skills to people of post-school age, as well as to promote in them attitudes and valuable behaviors aimed at fostering Personal and professional development, and social participation."

LLL comprises adult education and the "senior's room". The "senior's room" are university programs that have their own character, move away from regulated education and approach "formal-educational" and "educational-sociocultural" [4, 5].

We will address those aspects related to the perception of older adults who participate in academic contexts rather than their mathematical difficulties. The "calculation" requires a series of cognitive processes that include the capacity for reasoning, the identification of numerical and operational meaning. In this sense, it includes aspects such as problem solving and the implementation of strategies that allow solutions to proposed mathematical problems in the classroom or in daily life. We also analyze the factors that influence largely a negative perception about mathematical difficulties.

\section{Method}

The purpose of our research has focused on studying the elderly in an educational context. We want to know your perception of your "calculation" skills. The research question is: What perception do older adults have about their personal cognitive dimension of "calculation"?

The objective of the research is to know the perception of the cognitive personal dimension of "calculation" of the older adult students that is in the "senior's room".

The specific objectives disaggregated are: a) Analyze the opinion that the older adults have on their "calculation" competences; B) To discover the relational magnitudes between the self-perception of the competences of "calculation" and the sociodemographic variables.The sample is 448 subjects, over 50 years, who attend courses and educational programs with a marked socio-cultural character. The questionnaire is a Likert scale, with the following conceptual range: "Strongly Agree", "Agree", "Disagree", "Strongly Disagree".

\section{Results}

Analyzing the data obtained, we can roughly state that it is a constructive, active and strategic process in which the older adult has obtained positive results.

1. They have been asked if they are slow to perform calculations. $65.4 \%$ believe that they are not slow in performing calculation operations $(31.7 \%$ are Strongly Disagree and $33.7 \%$ are Disagree. To make calculation operations: "Agree" (22.5\%) and "Strongly Agree" (9.4\%). 
2. They have been asked if they have difficulty understanding mathematical concepts. They respond "Strongly Disagree" 26.9\%, "Disagree" 30.5\%, "Agree" 28.5\% and "Strongly Agree" 11.4\%.

Broadly speaking, we can say that the older adult considers that it is not slow to perform calculation operations, as well as in the processes of understanding mathematical concepts, although sex and the level of studies are determining factors to be aware of. Next we will see the relational data.

We emphasize that in the difficulties calculation we have detected aspects that influence in a relevant way, such as sex (table 1) and the level of studies (table 2), the years worked (table 3) and age at which they started to work (table 4).

Among the most significant significant relationships in this sense, men have less "Difficulties of calculation" ( $\mathrm{p}<0.001)$ (table 1).

Table 1. Sex.

\begin{tabular}{|c|c|}
\hline & $\begin{array}{c}\text { Difficulties } \\
\text { calculation } \\
(\mathbf{p}<\mathbf{0 . 0 0 1})\end{array}$ \\
\hline Man & 31,31 \\
\hline Woman & 42,38 \\
\hline
\end{tabular}

Those who have a basic level of education, mainly primary studies, have more difficulty in calculation $(\mathrm{p}<0.001)$ (table 2$)$. Those who have the greatest difficulty in calculating are those who have worked between 16 and 25 years.

Table 2. Level of studies.

\begin{tabular}{|c|c|}
\hline Primary & $\begin{array}{c}\text { Difficulties } \\
\text { calculation } \\
(\mathbf{p}<\mathbf{0 . 0 0 1})\end{array}$ \\
\hline $\begin{array}{c}\text { High School } \\
\text { / } \\
\text { Baccalaureat } \\
\mathrm{e}\end{array}$ & 35,4795 \\
\hline $\begin{array}{c}\text { Technical/ } \\
\text { FP }\end{array}$ & 27,7778 \\
\hline Higher/ \\
University
\end{tabular}

Those with the greatest language and calculation difficulties are those who have worked between 16 and 25 years (table 3 ). 
Table 3. Years worked.

\begin{tabular}{|c|c|}
\hline & $\begin{array}{c}\text { Difficulties } \\
\text { calculation } \\
(\mathbf{p}<\mathbf{0 . 0 5})\end{array}$ \\
\hline $\begin{array}{c}\text { Less than 5 } \\
\text { years }\end{array}$ & 40,4762 \\
\hline $\begin{array}{c}\text { Between 5 } \\
\text { and 15 }\end{array}$ & 43,8889 \\
\hline $\begin{array}{c}\text { Between 16 } \\
\text { and 25 }\end{array}$ & 59,4203 \\
\hline $\begin{array}{c}\text { Between 26 } \\
\text { and 35 }\end{array}$ & 31,3008 \\
\hline More than \\
35 years
\end{tabular}

With a low degree of significance $(\mathrm{p}<0.05)$, they have more difficulty in calculating those who started working after age 40 and before age 12 . The rest of the sample does not reflect a great difficulty of calculation, nevertheless, those who began to work between the 31 and the 35 years find that they have less difficulties in this respect (table 4).

Table 4. Started to work.

\begin{tabular}{|c|c|}
\hline & $\begin{array}{c}\text { Difficulties } \\
\text { calculation } \\
(\mathbf{p}<\mathbf{0 . 0 5})\end{array}$ \\
\hline $\begin{array}{c}\text { Before the } \\
\text { age of 12 }\end{array}$ & 51,6667 \\
\hline $\begin{array}{c}\text { Between the } \\
\text { ages of 13 } \\
\text { and 18 }\end{array}$ & 34,9638 \\
\hline $\begin{array}{c}\text { Between the } \\
\text { ages of 19 } \\
\text { and 25 }\end{array}$ & 38,2353 \\
\hline $\begin{array}{c}\text { Between 26 } \\
\text { and 30 years }\end{array}$ & 34,2105 \\
\hline $\begin{array}{c}\text { Between 31 } \\
\text { and 35 years }\end{array}$ & 16,6667 \\
\hline $\begin{array}{c}\text { Between 36 } \\
\text { and 40 years }\end{array}$ & 0 \\
\hline $\begin{array}{c}\text { After 40 } \\
\text { years }\end{array}$ & 70 \\
\hline
\end{tabular}

The purpose of our research has focused on studying the elderly in an educational context. We want to know your perception of your "calculation" skills. The research question is: What perception do older adults have about their personal cognitive dimension of "calculation"?

The objective of the research is to know the perception of the cognitive personal dimension of "calculation" of the older adult students that is in the "senior's room". 
The specific objectives disaggregated are: a) Analyze the opinion that the older adults have on their "calculation" competences; B) To discover the relational magnitudes between the self-perception of the competences of "calculation" and the sociodemographic variables.The sample is 448 subjects, over 50 years, who attend courses and educational programs with a marked socio-cultural character. The questionnaire is a Likert scale, with the following conceptual range: "Strongly Agree", "Agree", "Disagree", "Strongly Disagree".

\section{Conclusions}

Women, directly related to a low level of study, are more vulnerable to calculation difficulties; as well as those who have worked between 16 and 25 years and who began to work before the age of 12 . These factors analyzed could have influenced the educational and professional projection of the subjects surveyed.

Therefore, we affirm that quality of life and active aging are linked to the concept of lifelong education, which allows the development of higher capacities in the human being, together with the maintenance of cognitive, physical, social, psychological and Spiritual In this way, we make the following proposals: 1) To combat the existing myths and stereotypes in society from a series of target groups (the elderly themselves, students of professions linked to socio-educational intervention, 2) Bear in mind the determining aspects in this Population for the design of socio-educational intervention programs (sex and educational level, mainly); and 3) Promotion of lifelong education, as it is linked to quality of life and active aging.

If we follow the example of countries such as the UUEE or Japan, we must intensify policies in education and training, associating these actions with social welfare and improving competitiveness [6, p.115].

The challenges proposed by Sarrate and Pérez [13, p. 53] are: a) To respond to the demands of the knowledge society; B) Develop active and committed citizenship; C) Need to achieve a balance between the different dimensions involved - personal, cultural, civic, social, economic and labor - and democratic principles; D) To promote education in values as the axis of human development in all its dimensions.

\section{References}

1. M.R. Cruz Díaz, P. Moreno-Crespo, y Rebolledo Gámez, T. El alumnado universitario mayor ante los recursos tecnológicos y los medios de comunicación social: El caso del Aula Abierta de Mayores. En I Simposium Internacional sobre envejecimiento activo y solidaridad intergeneracional (pp. 1-14). Madrid: UNED, (2012)

2. J. M. Fernández Batanero, y Reyes Rebollo, M.M. Competencias emprendedoras del alumnado de educación permanente de Andalucía. Percepción del profesorado. Educación XX1, 20(1), 253-275 (2017)

3. C. Guerrero-Romera, Principales aportaciones de las conferencias internacionales de educación de adultos de la UNESCO al campo de la formación ocupacional. Educatio, 20-21, 185-212 (2003)

4. P. Moreno-Crespo, Mayores y formación: Aprendizaje y calidad de vida. En J.C. Gómez (Coord.), I Congreso Científico de Investigadores en Formación (281-283). Córdoba: Universidad de Córdoba, (2010)

5. P. Moreno-Crespo, Mayores y Formación. Aprendizaje y Calidad de Vida. Tesis Doctoral (no publicada). Sevilla: Universidad Pablo de Olavide, (2011) 
6. Moreno-Crespo, P. Educación a lo largo de la vida: aula de mayores. Revista Fuentes, 17, Diciembre, pp. 113-133 (2015)

7. P. Moreno-Crespo, M.R Cruz Díaz, Promoción de la calidad de vida a través de los programas socioeducativos para mayores: Universidad y mayores. En D. Cobos; A. Jaén, E. López, A.H. Martín y L. Molina (Coords.), I Congreso Virtual Internacional sobre Innovación Pedagógica y Praxis Educativa INNOVAGOGÍA 2012. Sevilla: AFOE, (2012)

8. P. Moreno-Crespo, E. Prieto Jiménez, L. Amador Muñoz, La necesidad de proyectos socioeducativos para mayores: el caso del aula abierta de mayores. Universidad Abierta: Revista de Estudios Superiores a Distancia (Ciudad Real), 29, 141-152 (2009)

9. G. Pérez-Serrano, Aprender a lo largo de la vida. Desafío de la sociedad actual. Ágora Digital, 1, 1-17 (2001)

10. E. Prieto-Jiménez, P. Moreno-Crespo, Diseñando programas para nuestros mayores: el caso del Aula Abierta de Mayores. En G. Pérez Serrano, J. García Gutiérrez y A. De Juanas Oliva (Eds.), V Jornadas de Calidad de Vida en Personas Mayores. Envejecimiento Activo y Participativo. Madrid: UNED, (2009)

11. M. F. Ríos-González, El contenido de la Educación Permanente en las conferencias mundiales de la UNESCO. Pedagogía Social. Revista Interuniversitaria, 10, 281-297 (2003)

12. C. Sabán Vera, "Educación Permanente" y "Aprendizaje Permanente": dos modelos teóricos-aplicativos diferentes. Revista Iberoamericana de Educación, 52, 203-230, 2010.

13. M. L. Sarrate, M. V. Pérez, Educación de Personas Adultas. Situación actual y propuestas de futuro. Revista de Educación, 336, pp. 41-57 (2005) 